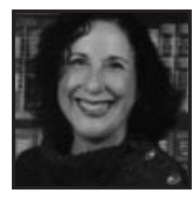

\title{
The Poetics of Self-Study: Getting to the Heart of the Matter
}

\author{
Margaret Louise Dobson, McGill University
}

\section{ABSTRACT}

This paper illustrates what poetic inquiry may contribute to teaching and learning. By using four samples of my own poetry, I demonstrate how the poetics of self-study can release the inner voice in ways that perhaps more conventional forms of research may not. Poetry removes the insulation between me and my experience to reveal what is "true" for me. Reading my own poetry as text has reinforced my educational convictions: It is who we are, not what we do (Arendt, 1974, p. 179) that will determine the success of our best classroom practices.

ife without poetry is unimaginable. Imagery is to poetry what fact is to prose. Hard, cold facts are necessary, but without imagination, life would be unthinkable. When I was a child it was poetry that put the bounce in my step, the skip in my stride, and the pump in my swing. To this day I can still find delight in the magical beat and wondrous images of favourite nursery rhymes: "Hickety Pickety My Black Hen/She lays eggs for gentlemen" (1955, p. 39) or A.A. Milne's "They're changing guard at Buckingham Palace/Christopher Robin went down with Alice" (1924/1958, p. 8). A secret garden of verse reverberates at the very core of my childhood memory. The poetic memories of my now-grown children, I am sure, would go more along the lines of Dr. Seuss' "Green eggs and ham/Sam I am" (1960, p. 7). My Québécois neighbour, perhaps, would recant a litany of "Bée, bée mouton noir/As-tu de laine? Oui monsieur, oui monsieur, trois poches pleines" $(1976$, p. 1). (It is all the same. In whatever form, poetry is the voice of the heart. Poetry touches the essence of what it means to be human in any generation, in any language, in any culture. We cannot live without it. Poetry is what binds our humanity together. 
Educators are faced with the seemingly impossible task of unifying human diversity in the pluralist Global Era in which we now find ourselves. How do we educate our youth for an individual life of meaning and purpose while maintaining a viable comprehensive community that will protect the living Earth home that we share interdependently? Theories abound. Political philosophers suggest multiple versions of Liberalism, Universalism, and Cosmopolitanism, to name only three ideals advocated by Western educational thinkers. Expansive, detailed proposals for civic education are hotly debated in the academic literature of modern educational thinkers. No matter how brilliant the ideals, it will be the largesse of compassion in the hearts of teachers in the classrooms, and educational leaders in the schools, that will determine the well-being of present and future generations. Political theories are needed, and we have them, thankfully; however, we must also turn to the arts and humanities if we are to truly transform education for the $21^{\text {st }}$ Century.

In this paper I propose self-study and poetic inquiry as two powerful agents to assist in the revitalization of our profession. We need, finally and literally, to get to the heart of the educational matter. It is who we are as teachers, not just what we do, that will determine the success of our best classroom practices. All arts-based research will be useful in that regard; but poetry, in particular, serves as a vital medium for self-study because the poetic expression requires a different orientation of thought than most of us non-artist types have been used to. Poetry seeks to retrieve the intuitive, an all-too-often ignored sensibility that many years of formal schooling and adult living may have dulled, or even dismissed altogether.

I have spent many rewarding years in Quebec and Ontario classrooms and schools. Over time, I must confess, I have grown weary and wary of the newest and latest programs designed to accommodate the forces of change and touted as "Reform." Like old bottles with new wine, they break. The potent wine of today has real legs! I am not certain anymore that we can organize and formalize humanity into behaving herself in a reasonable fashion according to our latest political theories about what is, and what is not, acceptable. Despite our best intentions, most people, like poetry, seem to want to go their wayward way. They are no longer inclined to follow a predetermined "garden path" to "whatever." Whatever it is, they want to do it "My Way!" Doesn't that sound like free verse wanting to escape the confines of the more traditional poetic structures of the past? Are educators to try to convince their students otherwise? Or, can we give them permission to discover their own free spirit and to live their own uncertain lives? Can we find it in our hearts to understand that it is no longer our business to mould and shape future generations in what was once, perhaps, just our own fearful quest for certainty? Can we actually release the 
imagination of human potential? The answer lies in "Only if we can do it for ourselves, first." Shakespeare, a great poet and connoisseur of the human condition, strongly urged many years ago, "To thine own self be true ..." (1599-1600 / 1947, p. 31). Of all the knowledge that we have amassed over time, "self" and "true" seem to be the last frontiers, and the hardest to get at! Going forward on the journey of self-discovery, I am convinced that we will need more than science and technology; we will sorely need the poetics of the heart.

Two main "events" caused me to choose poetry and self-study for my current research. First, it was the unplanned "accidents" of my own poems that put me more closely in touch with many of my heartfelt educational convictions. As an educational leader I was in the habit of writing up matter-of-fact reports, school plans, grants and letters to parents. When I had the chance upon my "retirement" to take a creative writing course at McGill, I wanted to see if, after all these years of writing on others' behalf, I could still find a "voice" of my own. Was there an original creative thought? Throughout the course, each week's exercise was to write creatively using a particular "assigned" word. We would then read the prepared text to the nineteen other participants in the class and receive critical feedback. Of course I was expecting to write prose; but more often than not, what I got was poetry! Poetry told me forgotten secrets that lay dormant under the surface of my life. Poetry seemed to remove the insulation between myself and my experience in a way that felt "true" as no other form of expression did. The element of surprise in creative writing piqued the interest of my educational instincts. The other aspect of intrigue was the fact that I kept returning to childhood memories whenever I searched for creative inspiration. Why? Is there no creativity in my adult life experience? What is there about the intensity of childhood memory that seems to get lost in adulthood? Secondly, I have learned in my doctoral studies the value of self-study as an entry point to a deeper understanding of the human condition. What is true for me, may also be true for you, and possibly, for us. I share the following poems with you, not for their aesthetic value, as you will see, but for their possible educational value. The selected poems, and many others not included, have taught me priceless lessons about myself, and, therefore, potentially, about the human condition. They touch on topoi, the common everyday concerns of people everywhere: spiritual and social identity; imagination and achievement; freedom; time. I offer some of my own reflections as part of the selfstudy as well as the ideas of others. My intention is to better understand my own human nature and to discern from that understanding a new direction and possibility for a revitalized educational experience that will be vibrant, creative and beautiful, not just political, instrumental and practical. My hope is that you will enjoy the poems for what they are, and that you may see something in them of our shared experience 
and educational concerns. Perhaps you will even be inspired to try your hand at the poetics of self-study!

\title{
Identity Rooted in Childhood
}

The first poem in the series is "Wild Violets." It was while writing this poem three years ago that I became aware, through memory, of the powerful presence of the past radiantly affecting the present. "Wild Violets" came as a surprise because of the accuracy and intensity of the feelings it conveys about a particular space, place and time of my childhood. So vivid is the memory, in fact, I am certain that I could take you on the road today to the field, and find the exact spot where, as a four-year-old, I lay down in the grass to become better acquainted with the violets. This little poem conveys my experience of what poet John O'Donohue (2007) calls the "inner music" that never abandons us. Henri Bergson (1907) might have called the phenomenon élan vital, or the vital essence that animates our lives. The wild violets, known throughout the world as uncultivated meadow flowers, are barely noticeable in the grand scheme of things; yet, this lovely little flower represents for me the quiet, assured endurance and confidence that is well rooted in my memory of childhood.

\section{Wild Violets}

\author{
Purple and mauve \\ Newly born shy \\ Nestled sweetly in the meadow grasses \\ Safely hidden \\ From the irreverent eye \\ (I must fall down \\ Flat on my belly \\ Just for a glimpse) \\ The large grey field stone \\ Stands solid there \\ Shielding the tiny protégés \\ While revealing, \\ By gracious contrast,
}




\section{The tender reticence}

of crimson blue

Do not be fooled

By their naïveté

There is nothing shrinking

About this savage bunch!

Slowly and surely

Throughout the years

Their tiny roots

Have grown strong and deep

Insisting their way

Through my restless sleep

What once appeared harsh and dark

Is now overcome

By the lavish hue

Of wild violets

"Attention to life" is described by Bergson (1991) as "a greater dilation of the whole personality" ... "the unscrewing of the vice in which it has allowed itself to be squeezed" (p. 14). A state of consciousness that has not been "narrowed down," says Bergson, is "whole and undivided, spreads itself over a wider and wider surface" (p. 14). Why is there a "narrowing down" of consciousness? What part has schooling played in squeezing out the vitality of the "greater dilation"?

I see "the large grey fieldstone" as possibly representing the solid institutions of society, in their own way providing a safe haven for children. A problem can arise, however, when the protective structures of society become overbearing and stifle the creative energies of their protégés. Only when the innate intelligence of our intuitive nature is allowed to interplay with our learned intellectual nature is it that life takes on a glow, or "lavish hue," that shines from within and illuminates the world around us. I find the self-reflection of the above poem to be reassuring. It signifies a gradual awakening in consciousness that was rooted in early childhood. 


\section{Imagination and Achievement}

The following poem conveys another intensely felt childhood memory. "Musical Musing" differentiates between the innocence of inner imagination and the experience of intellectual achievement. One without the other is meaningless, as this poem signifies. The musical musing points to the fact that most people do not "hear" the inner music; nor do they seem to discern the empty sounds, accurate in execution, perhaps, but totally void of meaning. The poem is also a reminder that children live in a world that is rich in imagination, a sensibility that is often derided and dismissed by the insensitivity of jaded grownups. Sadly, adulthood for many has meant losing touch with the "inner music."

\section{Musical Musing}

Little strips of ivory paper

Pasted neatly side by side

Along the thick dark edge of the country-kitchen table

My imaginary piano

Head tossed back in sheer delight

I play with all my might

Up and down the carefully crafted keyboard

My imaginary song

Laugh all you want

At this childish game

Bewildered by your merriment

I wonder

Can you not hear the music with no sound?

*

A Baby Grand piano

(RCM) Levels I to VIII

Taught by a professional

Spine straight

Imaginary oranges under the palms

Scales, chords, arpeggios

Extraordinary technique 
Exclaim all you want

Over my digital agility

Surprised by your acclaim

I ponder

Can you not hear the sound with no music?

\section{Freedom}

The following poem reflects aspects of self-awareness that are as true today as they were when I was five years old."Life doesn't move toward goals, but away from restrictions," is an adage I relish. I like the fierce spirit of determination and the strong sense of identity in the face of conformity. There is a truth that defies conventional wisdom. Gaston Bachelard (1958/1994) writes in The Poetics of Space, "Contemporary poetry has introduced freedom in the very body of the language. As a result, poetry appears as a phenomenon of freedom" (p.xxvii). For Maxine Greene (1998), education for freedom is "perhaps the main theme of my life" (p. 18). "Freedom ... is the capacity to take initiatives, to begin" (Greene, p. 55).

\section{A Runaway}

People say

that running away

is cowardly

They say

that we should stay

and face the music

Not I

I pride myself in running away

Each time I run away

I run closer to myself

I run away from pettiness

and narrow-mindedness 
I make a mad dash away from sameness

\author{
I leave behind \\ Oppression \\ Outdated rules and regulations \\ Stifling beliefs \\ Stalemates (and stale mates!) \\ Organizational restrictions \\ And external restraints
}

Irreverence and irrelevance are not for me I am a runaway

In the "protest" literature of the 1960s, Greene (1988) recalls, there were strong arguments against the institutional presence of the public schools:

...schools were meant to impose certain value systems and constraints so that energies would be appropriately channelled to suit the requirements of society... There was something basically at odds, it was said, between the demands of society and the requirements of human growth. (p.53)

The argument still holds true in conversations about education today. "How much does the possibility of freedom depend on critical reflectiveness, on self-understanding, on insight into the world?" "How much does it depend on the integration of the felt and the known, the subjective and the objective, the private and the public spheres?" (Greene, p. 53)

\title{
Time
}

The next two poems are about time, "Nowhere" and "Now Here." How do we find a fruitful interaction between our original spiritual identity and our constructed and reconstructed social identity? Finding the interaction or what I prefer to call a "synthesis" between who we are and what we are presents a significant challenge. "What is at stake is the revelatory character without which action and speech would lose all human relevance" (Arendt, 1974, p. 182). Reading the two poems out loud, I can feel the difference between artificial man-made time,"nowhere," and natural time where past, present and future are fused, "now here."The feeling speaks volumes. 


\section{Nowhere}

"I'm late; I'm late

For a very important date

No time to say

Hello Goodbye

I'm late; I'm late; I'm late."

(Lewis Caroll's White Rabbit)

It's a post-modern habit

We're short on time

We're out of breath

We have no rhyme

Or reason left

Hurry, scurry \& worry

We quicken the pace

Of frantic endeavour:

The human race

We must save the planet

We must win the war

On terror, on greed, on problems galore

We must get ahead

Be fast on our feet

We must beat the crowd

To make our ends meet

a.s.a.p.

No time for delay

For time is money

The bankers say

(We are running

Out of both

The naysayers say)

There has to be another way! 


\section{Now Here}

Once upon a time there was time

Do you remember that time?

There was time for tea

Time for play

And time to just be

Time to climb a tree

Or lie in the grass

And gaze at the clouds

And fly

High in the sky

Time for a song to sing

Time to reach for the tips of the leaves

With the tips of your toes

On the old rope swing

To and fro'

The ebb and flow

The natural rhythm

Of time

Time to bake a cake

Time to contemplate

The shape of an iris

Beside the lake

With time on your hands

You could hold the baby chick

And feel and smell

The soft pungent promise

Of magic

The robin's song tells

The time to go to bed

The kitten purrs

The time to get up

There is always time

Once upon a time 
How do we bring together the stillness of inner being with the bus-i-ness of outer achieving? I am grateful to remember a time when I felt at home in time, at home in the universe. For many of us, that time was childhood. What is time? Or, where is time? "However brief we suppose any perception to be, it always occupies a certain duration, and involves, consequently, an effort of memory which prolongs, one into another, a plurality of moments" (Bergson, 1991, p. 34). The duration of time is a key to the resolution of who I am and what I am. I am certain that this phenomenon is what John Keats was writing about in a letter:"I now feel more and more every day, as my imagination strengthens, that I do not live in this world alone, but in a thousand worlds." (1818/1963, p. 383). I am still present now in my memory of time "now here." As a result, I see children in a different light. Children may be small in size and inexperienced in the ways of the world, but they are wholly present in time.

\section{Conclusion}

In turning to the poetics of self-study to represent my research interests, I have been able to explore language in an effort to break out of the traditional moulds of academic investigation to get to the heart of the matter. I want to convey the invisible, the immeasurable, the intrinsic as essential elements of education. I feel that half the picture has been left out of the educational equation because we haven't been able, or quite ready perhaps, to talk about things like "intuition" or "heart" or "soul." Scholarly writing with its matter-of-fact intellectual tone can be a harsh medium for the expression of the delicate and passionate matters of the heart. "... poetry, rather than being a phenomenology of the mind, is a phenomenology of the soul" (Bachelard, 1958/1994, p. xx). Poetic inquiry has given me a certain permission to begin to uncover what I perhaps could not have conveyed in more conventional forms of research methodology. The methodology has also allowed me to examine topoi, topics common to our shared humanity. Whether we are consciously aware of the fact or not, we put our heart and soul, not just our minds, into teaching and learning. My poems about childhood memories have put me in touch with my "original way of being... that cannot be socially derived, but \{is\}inwardly generated" (Taylor, 1991, p. 47). Poetry has given me the courage and the vocabulary to begin to talk about what I know of "self" and "true." 


\section{References}

Arendt, H. (1974). The human condition. Chicago: University of Chicago Press.

Ayers, W.C., \& Miller, J.L. (Eds.). (1998). A light in dark times: Maxine Greene and the unfinished conversation. New York: Teachers College Press.

Bachelard, G. (1994). The poetics of space: The classic look at how we experience intimate places. John R. Stilgoe (Ed.), Maria Jolas (Trans.). Boston: Beacon Press.

Bayley, N. (Illus.), \& Parisot, H. (Trans.). (1976). Comptines de la mère l'oie. Italy: Flammarion.

Bergson, H. (1907). L'Evolution créatrice. Paris: PUF (Publication universitaire de France).

Bergson, H. (1991). Matter and memory. Nancy Margaret Paul \& W. Scott Palmer (Eds.). New York: Zone Books.

Greene, M. (1988). The dialectic of freedom. New York: Teachers College Press.
Keats, J. (1963). John Keats. (Letter, October 1818). (Walter Jackson Bate, Ed.). Cambridge: Belknap Press of Harvard University.

Milne, A.A. (1958). The World of Christopher Robin. Canada: McLelland \& Stewart.

O'Donohue, J. (2004). Beauty: The invisible embrace. New York: Harper Collins Publishers Inc.

Opie, I., Opie, P., \& Hassall, J. (Eds.). (1955). The Oxford nursery book. Oxford: University Press.

Seuss, Dr. (1960). Green eggs \& ham. Toronto: Random House of Canada.

Shakespeare, W. (1947). The tragedy of Hamlet prince of Denmark. New Haven: Yale University Press.

Taylor, C. (1991). The malaise of modernity. Cambridge, MA: Harvard University Press.

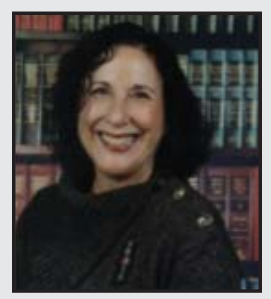

Margaret Louise Dobson is a PhD student in the Faculty of Education at McGill University. Prior to entering the doctoral program, she was a high school teacher of French and English, language supervisor for the Simcoe County Board of Education, and co-author of a K-13 audio-visual program, Le francais partout, published by Holt, Rhinehart and Winston. While raising her family and teaching in Ontario, she animated an ETV series for teaching FSL across Canada. Returning to her native province in 1984, she taught English literature to adult students before taking on leadership responsibilities as center director, vice-principal, then principal for the English Montreal School Board. 